\title{
Dehşet Yönetimi Kuramı Çerçevesinde Benlik Saygısı ve Bağlanmanın Rolü
}

The Roles of Self-Esteem and Attachment within the Framework of Terror Management Theory

Volkan Koç ${ }^{1}$ (D), Gülnihal Kafa ${ }^{2}$ iD

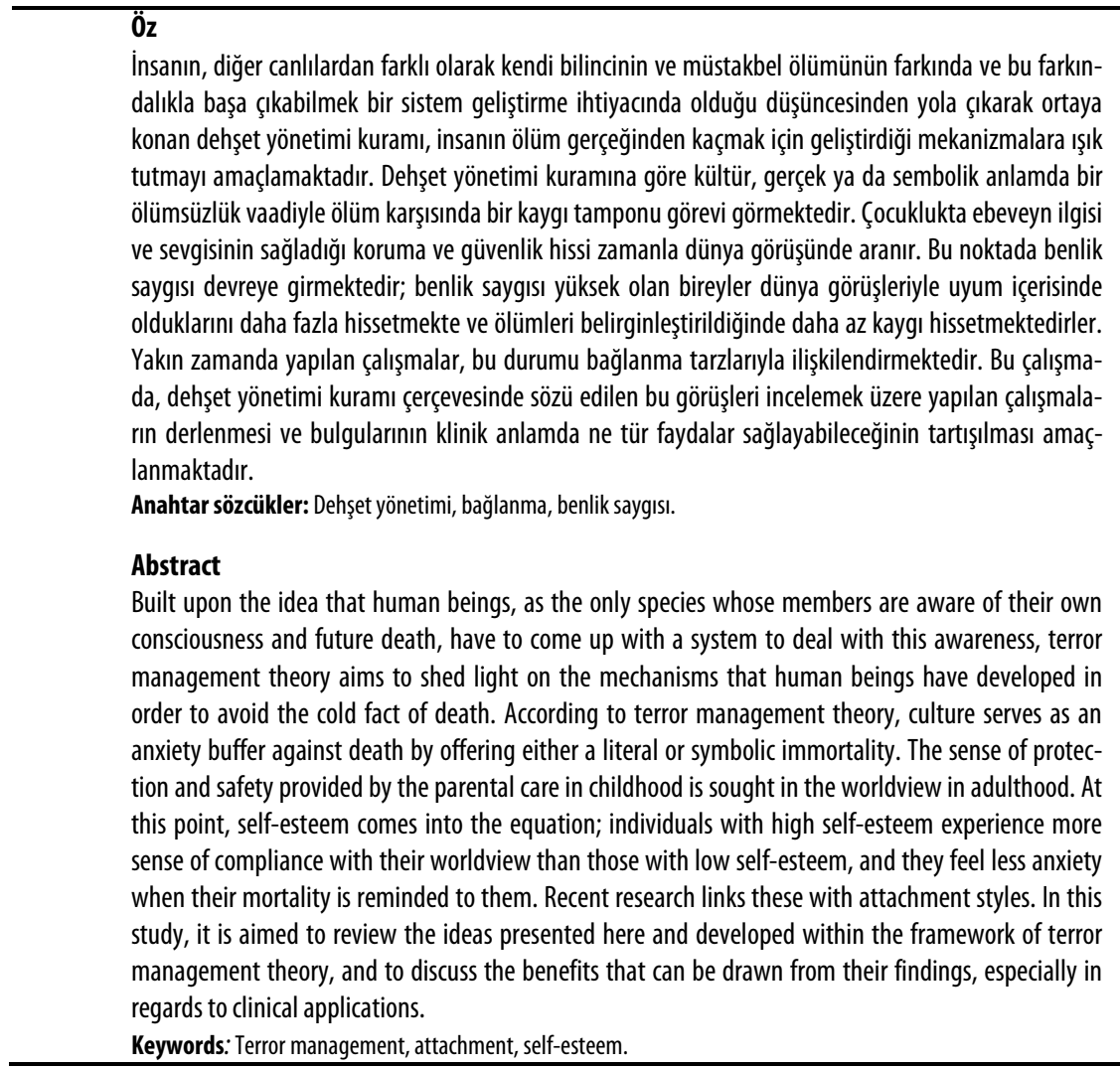

\footnotetext{
${ }^{1}$ İstanbul Sabahattin Zaim Üniversitesi İnsan ve Toplum Bilimleri Fakültesi Psikoloji Bölümü, İstanbul

${ }^{2}$ İstanbul Üniversitesi, İstanbul

$\triangle$ Volkan Koç, İstanbul Sabahattin Zaim Üniversitesi İnsan ve Toplum Bilimleri Fakültesi Psikoloji Bölümü, İstanbul, Turkey volkan.koc@izu.edu.tr

Geliş tarihi/Submission date: 27.04 .2018 | Kabul tarihi/Accepted: 22.06.2018 |Çevrimiçi yayın/Online published: 17.07.2018
} 
YAŞAMDA anlam, farklı bilim insanlarınca farklı şekillerde tanımlanmış olmakla birlikte, kişinin kendisi ve yaşam deneyimleriyle ilgili tutarlı bir algıya ve bir amaç duygusuna sahip olması olarak görülebilir (Steger ve ark. 2015). Frankl (2009), hayattaki anlamın her kişi için birbirinden farklı olacağını ve bir reçete halinde sunulamayacağını, kişinin yaşamındaki eşsiz anlamı ancak kendisi bulduğu zaman tatmin edici olacağını düşünmektedir. Çok sayıda çalışma, yaşama anlam atfetmenin daha yüksek duygusal ve fiziksel sağllkla ilişkili olduğuna işaret etmektedir (Brassai ve ark. 2012, Steger ve ark. 2015). Yalom (2011), insanın yaşamına bir anlam atfettiğinde büyük bir egemenlik duygusu yaşadığını öne sürer. Anlam arayışının ise aynı şekilde etki yarattığını öne sürmek daha zordur; anlam arayışı her zaman anlamın varlığıyla sonuçlanmadığı gibi, yüksek kaygıyla da ilişkilendirilmektedir (Steger ve ark. 2008, Yek ve ark. 2017).

$\mathrm{Bu}$ anlam bulma arayışında önemli bir yere sahip konulardan biri de kendi ölümlülüğümüzdür. Ernest Becker (1973) "Ölümün İnkârı" adlı eserinde kendi ölümlülüklerinin doğurduğu kaygı ile baş etmek için insanların bir sistem geliştirme ihtiyacı duyduklarını belirtmektedir. Becker'ın bu düşüncesinden yola çıkarak Greenberg ve arkadaşları (1997) Dehşet Yönetimi Kuramını ortaya koymuşlardır. Sosyal psikoloji çalı̧̧malarında önemli bir yer edinen ve ekonomi, askeriye, politika, hukuk vb. alanlarla disiplinler arası çalışmalar için verimli bir çıkış noktası sunan bu kuram (Pyszczynski 2004, Arndt ve ark. 2005, , Chatard ve ark. 2007, Salisbury ve Nenkov 2016), ölüme ilişkin farkındalığımızın, duygu, düşünce ve davranışlarımız üzerindeki etkisine 1şık tutmaktadır. Diğer canlılardan farklı olarak kendi varlığına ilişkin bilince sahip ve varoluşsal devamlılığını sürdürme eğiliminde olan insan, aynı zamanda ölümlü olduğu gerçeği ile de yüzleşme durumuyla karşı karşıya kalmaktadır (Pyszczynski ve ark. 2004). Ölümü, ölmekte olanlara bırakmak olası değildir (Yalom 2011). Dehşet yönetimi kuramı ise, ölüm gerçeğinin ağırlığından kaçmaya çalışan insanın geliştirdiği bazı mekanizmaları açıklamaya çalışmaktadır (Greenberg ve ark. 1986). Bu çalışmada dehşet yönetimi kuramı çerçevesinde bağlanma ve benlik saygısının araştırıldığı çalışmaların derlenmesi amaçlanmıştır.

\section{Dehşet Yönetimi Kuramı}

Dehşet yönetimi kuramına göre, insanlar da hayvanlara benzer bir şekilde kendini koruma içgüdüsüne sahiptir, ancak onlardan farklı olarak kendi ölümleri hakkında düşünebilir ve bir farkındalık geliştirebilirler; bu da kişiyi büyük bir dehşete düşürme potansiyeline sahiptir (Greenberg ve ark. 1986, Simon ve ark.1998). İnsanların bu dehşetin üstesinden gelmesini sağlayan ise, yine insan topluluklarını hayvanlardan ayıran 'kültür'dür. Kültür, insanlar için bir anlam ve değer kaynağıdır ve kişi, kültürünün kendisine sağladığı değerlere uygun yaşadığ1 sürece kendisini de değerli hissedecektir (Greenberg ve ark. 1986).

\section{Kültürel Dünya Görüşü}

Bir kaygı tamponu olarak kültür, insana ölüm korkusuyla başa çıkabilmek için iki araç sunar. Bunlardan ilki kültürel dünya görüşüdür (cultural worldview). Kültürel dünya görüşü, kişiye evrenin düzenli ve istikrarlı, dolayısıyla öngörülebilir olduğu izlenimini vererek ölümün aslında ansızın gerçekleşebilecek bir olasılık olmadığı, dolayısıyla endişe etmesine gerek olmadığına dair içsel inancını pekiştirerek ölüm kaygısını azaltır. Daha da önemlisi, kişinin hayatına bir anlam ve amaç katar ve insan davranışları için bir standart sağlar; bu standartlara göre yaşayan insanlara gerçek ya da sembolik anlamda 
bir ölümsüzlük vaat eder (Arndt ve ark. 1997). Dini görüşler ölüm sonrası için açıklamalarda bulunurken, seküler görüşler de sembolik ölümsüzlüğü vurgulamaktadır (Jonas ve Fischer 2006, Hayes ve ark. 2010). Dehşet yönetimi kuramı çerçevesinde yapilan ve genellikle katılımcılardan a- kendi ölümlerinin ortaya çıkarttığı duyguları tanımlamaları ve b- öldüklerinde fiziksel olarak kendilerine ne olacağını düşünmeleri istenen ölümlülüğün belirginleştirilmesi (mortality salience) çalışmalarının sonuçları (Hayes ve ark. 2010), açık ya da örtük olarak ölümlü olduğunu fark eden/hatırlayan kişinin ortaya çıkan kaygıdan kurtulmak için dünya görüşüne daha fazla bağlanma ihtiyacı hissettiğine işaret etmektedir. Bu nedenle de kendi dünya görüşünü destekleyen insanlara ya da şeylere karşı olumlu tepki verirken, kendi dünya görüşüne karşı bir tehdit oluşturabilecek kişilere ve şeylere olumsuz tepki vermektedir. Bu da kişinin dünya görüşünü daha radikal bir şekilde savunmasına ve diğerlerinin inançlarını ve düşüncelerini reddetmesine ya da bu inançları ve inançların sahiplerini küçümsemesine yol açabilmektedir. (Harmon-Jones ve ark. 1996, Hayes ve ark. 2010).

Bu görüşü sınamak için Aksüt-Çiçek (2008) tarafından yapılan bir çalışmada da bireylerin hem dini eğilimleri tehdit edildiği hem de ölümlülükleri hatırlatıldığı durumda, yalnızca dini eğilimlerinin tehdit edildiği duruma göre daha fazla saldırganlık gösterdikleri sonucuna ulaşılmıştır. Dünya görüşünün ölüm karşısındaki koruyucu etkisini araştıran bir diğer çalı̧̧mada ise, ölümlülükleri hatırlatılan kadınların, fiziksel görünümlerini toplumsal normlara göre değerlendirme eğilimlerinde bir artı̧̧ olduğu ve sağlığa zararlı, yani bir diğer değiş̧le fiziksel anlamda ölümden uzaklaştırmak yerine ona daha çok yaklaştıran, bir zayıflama yöntemi olarak diyet haplarını kullanmaya daha olumlu baktıkları gözlemlenmiştir (Cihan 2013). Yavuz ve Van den Bos (2009) ölümleri belirginleştirilen ya da belirsiz bir durumda kaldıklarının hayal edilmesi istenen katılımcı gruplarının her ikisinin de kültürel değerlerinin tehdit edilmesi durumunda kontrol grubuna göre daha şiddetli tepki verdiklerini bildirmişlerdir. Ancak araştırmacılar, belirsizlik koşulunun ölümün hatırlatılması koşulundan daha fazla etki gösterdiğini, bu durumda Türkiye gibi belirsizlikten kaçınma eğiliminin yüksek olduğu toplumlarda, belirsizliğin ölümün hatırlatılmasından daha önemli olabileceğini belirtmişlerdir.

\section{Benlik Saygisı}

Kültürel kayg1 tamponunun (cultural anxiety-buffer) sunduğu ikinci araç ise, benlik saygisıdır (Arndt ve ark. 1997). Bebeklik ve erken çocukluk döneminde kişinin korunma, güvenlik ve değer görme ihtiyacı ebeveynler tarafından karşılanmaktadır ve çocuk büyüdükçe ebeveynlerinden gelen destek de koşullu olmaya başlar: eğer ebeveynlerinin istediği şekilde davranırlarsa istedikleri ilgiyi göreceğini, davranmazlarsa göremeyeceğini anlamaya başlar ve ebeveyninin kriterlerine göre hareket etmeye başlar. Çocuğun bilişsel fonksiyonları geliştikçe ölümlü ebeveynlerinden gördüğü ilgi yeterli olmayacak ve daha kalıcı ve üstün bir değer ve korunma kaynağı arayacaktır (Greenberg ve ark. 1986). Bunu ise ona kültürü sağlayacaktır. Kültürün sunduğu değerlere göre hareket ettikçe kişi güvende olduğunu hissedecek ve ailesinin istediği gibi bir çocuk olduğunda hissettiği değer duygusunu, kültürel dünya görüşüne uygun yaşadığı zaman hissedecektir. (Pyszczynski ve ark. 2004).

\section{Dehşet Yönetiminde Benlik Saygısının Önemi}

Dünya görüşüne sahip olmanın ölüm gerçeği ile baş etmekteki rolüne baktığımızda, 
yaşamda bir anlam algısına sahip bireylerin ölüme ilişkin farkındalıkları arttırıldığında (ölümlülük belirginleştirildiğinde), bir anlama sahip olmayan bireylere göre daha az ölüm kaygısı duydukları görülmektedir. Diğer bir ifadeyle yaşamda bireyin bir anlama sahip olması ölüm düşünceleri karşısında birey için tampon görevi görebilmektedir (Routledge ve Juhl 2010). Aynı şekilde sembolik ölümsüzlüğe ilişkin alg1sı yüksek bireyler de ölüme ilişkin farkındalıklarının artırılmasından daha az etkilenmektedirler ve daha az ölüm korkusu taşımaktadırlar (Florian ve Mikulincer 1998). Örneğin kişilerden öldükten sonra arkalarında nasıl bir izlenim bırakacaklarına dair düşünmeleri istendikten sonra yine ölümlülük belirginleştirildiğinde, kontrol grubunda yer alan bireylere göre daha az ölüm kaygısı hissetmektedirler (Wojtkowiak ve Rutjens 2011). Ancak bu etki iki yönlüdür; kişilerin kültürel değerlerine karşı (buna bir açıdan kişinin yaşamının anlamı da diyebiliriz) tehdit oluşturan bir durum gerçekleştiğinde, bireylerin ölüme ilişkin düşüncelerinin tetiklenebildiği de görülmektedir (Schimel ve ark. 2007).

Arrowood ve arkadaşları (2017) tarafindan geniş otizm fenotipinin görüldüğü bireylerle yürütülen bir çalışmada, daha katı bir kişiliğe sahip olan, yani değişime uyum sağlamakta daha fazla zorluk yaşayan bireylerin daha esnek bir kişiliğe sahip olanlara kıyasla daha fazla ölüm korkusu hissettiği, ölümlülükleri hatırlatıldığında daha yüksek ölüm kaygısı yaşadığı ve dünya görüşlerini daha şiddetli savundukları görülmüştür. Ancak dehşet yönetimi kuramınca, dünya görüşü ve benlik saygısı kişinin ölümle başa ç1kmasında birlikte hareket etmektedir. Her ne kadar bir dünya görüşüne sahip olmak ve yaşama bir anlam atfetmek ölüm karşısında bireyin baş etmesine yardımcı bir etken olsa da Arndt ve arkadaşlarının (1997) özellikle vurguladığı gibi dehşeti yönetmede benlik saygısı da büyük bir önem taşımaktadır. Zira benlik saygısı düşük olan birey, kendi dünya görüşü ile uyum içinde olduğuna ilişkin algısını pekiştiremeyebilir ve bireysel olarak varlığına önem atfedemiyor olabilir. Taubman Ben-Ari’nin (2011) çalışması bu görüşü destekleyecek niteliktedir ve ölümlülük belirginleştirildiğinde yüksek benlik saygısına sahip bireylerin yaşamlarını, düşük benlik saygısına sahip bireylere göre daha anlamlı bulduklarını göstermektedir.

Dehşet yönetimi kuramında önemli bir yer tutan benlik saygısının, ruhsal iyilik hali açısından önemi bilinmektedir (Orth ve ark. 2008). Yüksek benlik saygısına sahip bireylerin, kendi niteliklerine ilişkin açık bir görüşleri vardır ve belirli hedefleri bulunmaktadır. Yine bu bireyler benliklerine olumlu atıflarda bulunmaktadırlar ve karşılaştıkları koşullarla sağlıklı bir şekilde baş etmektedirler (Leary ve ark. 1985, Brown ve ark. 2001). Bununla birlikte düşük benlik saygısına sahip kişilerin benliklerine yönelik net bir bakışlarının olmadığı ve olumsuz baktıkları, benlik değerlerini yükseltmede zorluk yaşadıkları görülmektedir (Josephs ve ark. 2003)

Hem ruhsal iyilik halimiz de hem de dehşet yönetiminin etkin bir şekilde yapılmasında önemli bir rol taşıyan benlik saygısı ile ölümlülüğün belirgin yapıldığı durumlar karşısında bireylerin tepkileri çeşitli çalışmalarda ele alınmıştır. Bu çalışmalar aynı zamanda kuramın doğrulanması için de önemli bir yere sahiptir. Greenberg ve arkadaşlarının (1992) benlik saygısının birey için önemini ve kaygı uyandıran durumlar karşısındaki tampon görevi taşıdığını göstermek için bir dizi çalışma gerçekleştirmişlerdir. Dehşet yönetimi açısından çalışmada elde edilen en önemli sonuç, benlik saygısı deneysel bir ortamda yükseltildiğinde, bireylerin ölüm düşüncelerini uyandıran uyaranlar karşısında daha az kaygı duydukları olmuştur. Herhangi bir müdahalede bulunulmadan benlik saygısı yüksek ve düşük bireyler karşılaştırıldığında ise Harmon-Jones ve arka- 
daşları (1997); ölümlülüğün belirginleştirildiği bireylerde, benlik saygısı yüksek kişilerin ölüm düşüncesi ile baş etmek için, benlik saygisı düşük olan kişilere göre dünya görüşlerine bağlanma savunmasını daha az kullandıklarını bildirmişlerdir.

Yukarıda aktarılan çalışmaların aksi yönünde sonuç veren çalışmaların da (Landau ve Greenberg 2006, McGregor ve ark. 2007) varlığına dikkat çekerek buna bir açıklama getirmeye çalışan Schmeichel ve arkadaşları (2009) çözümün farklı benlik saygısının çeşitlerinde yattığ1 sonucuna varmıştır. Buna göre, ölüm düşüncelerine karşı tampon görevi gören, kişinin kendini bilinçli bir şekilde değerlendirmesinden kaynaklanan açık benlik saygısından ziyade, bilinçli farkındalığın kapsamına görece daha az giren örtük benlik saygısıdır. Dehşet yönetimi kuramı ile uyumsuz sonuçlar veren çalışmalar ise daha "içgüdüsel" olan örtük benlik saygısına değil, bilişsel çarpıtmalara ve benlik sunumu yanlılıklarına daha açık olan açık benlik saygısını dikkate almaktadır. Diğer yandan benlik saygısının varoluşsal tampon olarak işlevi üzerinde kültürel farklılıkların etkisini inceleyen Du ve arkadaşlarının (2013), toplulukçu kültürlerde karşılıklı bağımlı benlik saygısının, bireyci kültürlerde ise bağımsız benlik saygısının daha etkili olduğu sonucuna ulaşmışlardır.

Ölüm kaygısı karşısında öz saygının kullanımındaki bireysel farklılıkları açıklamaya çalışan Mert (2010), cesaret kavramının dehşet yönetimi kuramına dahil edilmesini önermektedir. Buna göre, cesaret korkunun yok edilmesi değil kontrol edilmesi olarak tanımlanabilir (Olsthoorn 2007) ve sahip olunan güçlerin ne kadar etkili bir biçimde kullanılabileceğini belirlemektedir, buna özsaygı da dahildir (Mert 2010).

Kişiyi ölüm kaygısından koruma noktasında birlikte çalışmaları beklenen benlik saygısı ve dünya görüşünün çatıştığı zaman neler olacağını inceleyen Landau ve arkadaşları (2009), kişinin benlik saygısını arttırma çabalarının dünya görüşünü temsil eden otoriteleri tehdit ettiği noktada benlik saygısını arttırma çabalarından vazgeçildiği sonucuna ulaşmıştır. Bunu dehşet yönetimi kuramı çerçevesinde dünya görüşünün ölüm kaygısına karşı benlik saygısından daha temel bir tampon işlevi görmesiyle ilişkilendirmişlerdir. Çünkü, bu araştırmacılara göre, kişinin dünya görüşünün tehdit edilmesi benlik saygısının üzerine inşa edildiği değerlerine de zarar verirken, benlik saygısının zedelenmesi dünya görüşünü tehdit etmek zorunda değildir. Du ve Jonas (2015) tarafından yürütülen ve doğu toplumlarının kültürel değerlerinin bir parçası olan alçakgönüllülük normuna uygun davranmanın, kişiye ölümlülüğü hatırlatıldığ1 zaman benlik saygısı üzerindeki etkisini inceleyen bir başka çalışma ise, araştırmacıların dehşet yönetimi kuramı doğrultusunda öne sürdükleri hipotezi yanlı̧layıp kişinin benlik saygısını düşürdüğü sonucunu ortaya koymuştur. Bu araştırmacılar dehşet yönetimi kuramı çerçevesinde toplumsal normlara uygun davranmasının sonucunda benlik saygısının artmasını beklerken araştırmanın tersi yönde sonuç verdiğini görmüştür. Hatta Landau ve arkadaşlarının (2009) yukarıda verilen çalışmasıyla uyumsuzluk gösterecek şekilde, bir toplumsal norm olarak alçakgönüllülük normunu ihlal etmenin benlik saygisını arttırdığını bildirmişlerdir.

\section{Dehşet Yönetimi Kuramı ve Bağlanma}

Dehşet yönetimi kuramı için temel olan benlik saygısının önemini araştırmalarda da görebilmekteyiz. Benlik saygısının gelişimi, işlevleri ve kökeni üzerine sayısız çalı̧̧ma gerçekleştirilmiştir (Leary ve ark. 1995, Kuster ve ark. 2013, Orth ve Robins 2014). Araştırmalar, benlik saygısının kişinin yaşamı boyunca belirli bir değişim göstermekle 
birlikte (Orth ve Robins 2014, Chung ve ark. 2017), kişiler arasındaki farklilıkların çocukluktan itibaren istikrar gösterme eğiliminde olduğuna işaret etmektedir (Cole ve ark., 2001; Donnellan ve ark.2012). Genetik faktörlerin yanı sıra erken çocukluk döneminde içinde bulunulan çevre ve bakıcıyla ilişkiler, benlik saygısının oluşumu üzerinde nispeten büyük ve kalıcı bir etki bırakmaktadır (Verschueren ve Marcoen 1999, Orth 2018).

Bağlanma kuramının öncülerinden Bowlby’e $(1985,1989)$ göre, bağlanma figürüyle olan etkileşimler zihinsel temsiller (bağlanma figürünün tepkilerine ilişkin modeller) şeklinde kaydedilmektedir. Aynı zamanda birey bağlanma figürüyle olan etkileşimine göre benliğine ilişkin de modeller oluşturmaktadır. Çocuğun bağlanma sürecinde; bağlanma figürünün destek ve güvenlik için çağrıldığında gelmesi ya da gelmemesi ile çocuğun kendini bağlanma figüründen yardım almaya layık birisi olarak algılayıp algılamaması önem taşımaktadır ve benlik algısı bu çerçevede şekillenmektedir. Aynı zamanda bu süreçte birey duygusal deneyimleri düzenleyen ve yaşam boyu zorluklarla baş etmesinde rehber olan içsel çalışan modeller oluşturmaktadır. Dehşet yönetimi kuramına göre (Pyszczynski ve ark. 2004) bağlanma sürecinde kaygı ile baş etmek için ebeveyn ile kurulan ilişki, ölüm karşısında duyduğumuz kaygı ile baş etmekte kullandığımız yol ile benzerlik taşımaktadır. Yukarıda da açıklandığ 1 gibi, ölümlü olduğumuz gerçeği bireyin ilerleyen yıllarında daha açık bir hal aldığında, ebeveynin koruyuculuğu azaldığı için birey dünya görüşüne bağlanarak ölüme ilişkin kaygısını yatıştırmaktadır.

İnsan yaşamında bu kadar merkezi bir rol oynayan bağlanmanın, dehşet yönetimi üzerindeki etkisine ilişkin çalışmalara bakıldığında, öncelikle bağlanma stilinin bireylerin ölüm korkusu üzerinde etkisinin olduğunu ve güvenli bağlanmanın bireyin kendi ölümüne ilişkin korkusunu azalttığını görmekteyiz (Mikulincer ve ark. 1990, Florian ve Mikulincer 1998, Mikulincer ve Florian 2000). Fakat ölüm korkusu aç1k olarak sorgulandığında güvenli ya da güvensiz bağlanmanın öneminin azaldığı, ancak bununla birlikte örtük ölüm korkusunun daha çok güvensiz bağlanmada görülebildiği dikkat çekmektedir (Mikulincer ve ark. 1990).

Daha önce de vurgulandığı üzere Florian ve Mikulincer (1998), çalı̧̧malarında sembolik ölümsüzlüğe ilişkin algısı yüksek olan bireylerin ölüm korkularının daha az olduğunu göstermişlerdir. Aynı çalışmada bağlanmanın da belirleyici bir durum olabileceği düşüncesinden yola çıkarak ölüm korkusu üzerindeki etkisine bakılmıştır ve beklendiği gibi güvenli bağlanmaya sahip bireylerin sembolik ölümsüzlük algısı geliştirmelerinin daha kolay olduğu ve bu algının ölüm korkusu ile baş etmede olumlu bir etken olduğu görülmektedir. Bu doğrultuda olumlu erken dönem yaşantılarının bireyin yaşam ve ölüme ilişkin daha pozitif bir düşünce geliştirmesine katkı sağladığı düşünülebilir. Ancak çalışmanın ilginç sonuçlarından birisi, kaçıngan bağlanmaya sahip bireyler her ne kadar sembolik ölümsüzlüğe ilişkin olumlu bir algıya sahip olmasa da bu durumun ölüm korkusu üzerindeki etkisi görülememiştir. Araştırmacılar bunun bir savunma/inkardan kaynaklanabileceğini ifade etmişlerdir. Çalışmanın bu kısmında ölümün belirginleştirilmesi yöntemi yerine, kendini bildirim ölçeklerinin kullanılmış olması göz önünde bulundurulmalıdır. Bu eksiği dikkate alan araştırmacılar iki yıl sonra yaptıkları diğer bir çalışmalarında ölümün belirginleştirilmesi durumunda bireylerin bağlanma stillerinin dehşeti yönetmeleri üzerindeki etkisine bakmışlardır. Ölümün belirginleştirildiği durumda; sadece güvenli bağlanan bireylerde sembolik ölümsüzlük duygusunun ve yakın ilişkilerdeki samimiyet arzusunun arttığ1 dikkat çekmektedir. Bu sonuç güvenli bağla- 
nan kişilerin güvensiz bağlanan kişilere kıyasla ölümün belirginleştirildiği durumda baş etmek için farklı bir tepki verdiklerini düşündürmektedir. Çalışmanın önemli sonucuna göre, birey ister güvenli ister güvensiz bağlanmış olsun, ölümün belirginleştirilmesi durumundan bütün bireyler etkilenmektedir, ancak bağlanma stili bireyin baş etmek için izlediği yolu farklılaştırabilmektedir (Mikulincer ve Florian 2000).

Dehşet yönetimi açısından yakın ilişkilerin işlevini ele aldıkları bir çalışmalarında Mikulincer ve arkadaşları (2003), ölümün belirginleştirilmesi durumunda yakın ilişkiler kurma ve bu ilişkileri sürdürme motivasyonunun arttırdığını ve bu tür ilişkilerin ölüm korkusuna karşı sembolik bir kalkan sağladığını öne sürmüşlerdir. Hirschberger ve arkadaşlarının (2003) diğer bir çalışmalarında da katılımcılardan romantik partnerlerinin kendilerini övdükleri, kendilerinden şikâyet ettikleri ya da kendilerini eleştirdikleri durumları hayal etmeleri istenmiştir. Sonrasında katılımcıların partnerleriyle yakınlık arayışları ilk durumda en fazlayken üçüncü durumda en az olmuştur. Ancak aynı süreç ölümün belirginleştirilmesi koşulu altında tekrarlandığında, katılımcıların partnerlerinden ne tür geribildirim aldıklarından bağımsız olarak yakınlık aradıkları gösterilmiştir.

Bu ilişkiyi tersinden ele alan bir diğer çalışmada (Mikulincer ve arkadaşları 2002), yakın ilişki içinde oldukları birinden ayrı kaldıklarını hayal eden katılımcıların, özellikle ayrılık süresinin uzun olması ve kişinin bağlanma kaygısı yaşıyor olması durumunda, kendi ölümlülüklerine dair farkındalıklarının arttığı gözlemlenmiştir. Benzer bir araştırmada da katılımcılardan eşlerinden ayrıldıklarını hayal etmeleri istenmiş ve eşlerine daha yüksek bağlılık gösteren kişilerin daha az ölüm kaygısı yaşadıklanı görülmüştür (Dalda 2011). Taubman Ben-Ari ve arkadaşları (2002) bu çerçeveyi biraz daha genişletip sosyal ilişkiler ve dehşet yönetimi ilişkisine bakmışlardır. Bir dizi çalışmanın yapıldığı araştırmanın sonuçları genel olarak ele alındığında, ölüm belirginleştirildiğinde bireylerin sosyal etkileşime girme isteklerinin arttığı görülmüştür, ancak burada önemli nokta bu isteğin daha çok güvenli bağlanmaya sahip bireylerde görüldüğüdür.

Cox ve arkadaşlarının (2008), erken dönem ebeveyn ilişkilerinin bağlanmadaki merkezi rolünün altını çizerek, yakın ilişkilerin bağlanmayı değerlendirmek amacıyla kullanılmasının yeterli olmayabileceğini düşünmüşlerdir. Bu doğrultuda dehşet yönetimi üzerindeki etkisini araştırmak için erken dönem bağlanmanın da dikkate alındığı bir dizi çalı̧̧ma gerçekleştirmişlerdir. Öncelikle ölümün belirginleştirilmesi durumunda bireylerden pozitif ebeveyn temsilleri geri getirmeleri istendiğinde, bunun ölüm düşünceleri karşısında tampon görevi gösterdiği görülmüştür. Bu durum bağlanma stilinin etkisinin ötesinde, bağlanma figürüne dayanmanın etkili bir biçimde dehşeti yönetmeye katkı sağladığı düşündürmektedir. Ancak araştırmacılar pozitif ebeveyn etkileşimlerinin imgelenmesinin, doğrudan olumlu ebeveyn ilişkisi ile bağlantılı olmayabileceği ve bu imgelemelerin benlik değerini yükseltme üzerinde bir etkisinin olabileceğinin dikkate alınması gerektiği vurgulamaktadırlar. Aynı çalışmada ölümün belirginleştirildiği durumda güvenli ve güvensiz bağlanan kişilerin aradıkları yakın ilişkilere bakıldığında, güvenli bağlanan kişilerin romantik ilişkide oldukları kişiden destek alma eğilimi gösterdikleri, güvensiz bağlanan kişilerin ise ebeveynden destek alma eğilimi gösterdikleri gözlenmiştir. Benzer bir şekilde Cox ve Arndt (2012) da ölümün belirginleştirilmesi durumunda kayg11ı bağlanan bireylerin ebeveynlerinin kendileri ile ilgili pozitif görüşlerini abarttıkları, güvenli bağlanan bireylerin ise romantik partnerlerinin kendileri ile ilgili olumlu görüşlerini abarttıkları sonucuna ulaşmıştır. Ebeveynlik ile dehşet yönetimi arasındaki ilişkiyi inceleyen Yaakobi ve arkadaşları (2014), özellikle daha az kaçıngan 
bağlanan bireylerde kişinin kendi ebeveyn olma durumuyla ilgili düşüncelerinin kaygıya karşı tampon görevi gördüğünü ve romantik yakınlık gibi diğer dehşet yönetim mekanizmalarının aktivasyonunu önlediğini bulmuşlardır. Aynı çalışmada katılımcılardan çocuk sahibi olamama ihtimalleri düşünüldüğü zaman ise ölümle ilgili daha yüksek farkındalığa yol açtığı gösterilmiştir. Araştırmacılar bu sonuçları, çocuk sahibi olma arzusunun kısmen ölüm kaygısıyla başa çıkmakla ilgili olduğu şeklinde yorumlamışlardır. Ölümle ilgili düşünceler ile yakın ilişkiler arasındaki bu ilişkilerden yola çıkan Vance (2014) ise, aradaki bu güçlü ilişkiden terapi odasında da faydalanmayı ve ölüm korkusunun danışan-terapist arasındaki ilişkiyi geliştirmek için kullanılmasını önermektedir. Ayrıca ölüm kaygısının görmezden gelinmesinin danışana ve terapötik ilişkiye zarar verebileceğini belirtmektedir.

Dünya görüşü ile ilişkiye bağlllık arasındaki ilişkiyi inceledikleri bir çalışmada Strachman ve Schimel (2006), katılımciların bir kısmından romantik partneriyle aralarındaki farklılıklar üzerinde düşünmesini, bir kısmından ise romantik partnerleriyle aralarındaki benzerlikler üzerinde düşünmesini istemiştir. Bunun ardından ölüm belirginleştirildiğinde, partnerleriyle aralarındaki dünya görüşü farklllıklarına odaklanmış olan bireylerin partnerlerine bağl1lı̆̆ında azalma görülmüştür. Tongeren ve arkadaşları (2013) tarafindan gerçekleştirilen bir diğer çalışmada ise, ölümün belirginleştirilmesinin kişiyi yüksek bağlılık gösterdiği kişilere karşı daha affedici olmaya, düşük bağlllık gösterdiği kişilere karşı ise daha mesafeli olmaya ittiği görülmüştür. Araştırmacılar bu farklılığ1 kişinin dünya görüşünü korumaya çalışmasına bağlamaktadır; kişinin yakın ilişki içerisinde olduğu biriyle bağların kuvvetlendirilmesi varoluşsal bir güvenlik sağlayabilir ancak kendisine benzemeyen veya yakın ilişki içerisinde olunmayan biriyle ilişkileri kuvvetlendirmek kendi dünya görüşüne zarar verebilir.

Bu tür bulguları açıklama çabasında olan Hart ve arkadaşları (2005), bağlanma, öz sayg1 ve dünya görüşü süreçlerinden oluşan üç parçalı bir güvenlik sistemi modeli önermişlerdir. Buna göre, bu üç bileşenden birinin tehdit edilmesi durumunda, diğer bileşenler daha fazla aktif hale gelmektedir. Ayrıca kişinin bağlanma tarzının da bu savunma amaçlı aktivasyonun şiddeti üzerinde etkili olacağını öne sürmüşlerdir. Yürüttükleri çalışmaların sonuçları da bu modeli destekler niteliktedir.

\section{Sonuç}

Dehşet yönetimi kuramı oldukça ilgi gören bir yaklaşım olmakla birlikte, bu ilginin henüz yeni arttığını söylemek de mümkündür. Bundan dolayı bazı genellemelerde bulunmak henüz erken sayılabilir, ancak yine de elde edilen bilgilerin sosyal psikolojinin ötesinde birçok alana 1şık tuttuğunu görmekteyiz. Becker (1973) eserinde gelişimsel süreçte olumlu bir ortamda büyüyen insanın yaşayacağı ölüm korkusu yoğunluğunun daha az olacağını kabul etmekle birlikte, bu durumun bu korkuyu daha iyi örtebilmekle ilişkili olduğunu vurgulamaktadır. Dehşet yönetimi çalışmalarında da insanların bir şekilde bu korkuyu taşıdıklarını, ancak bu korkuyu yönetme biçimlerinin farklılaştığını görmekteyiz. Bağlanmanın insanın ruhsal iyilik hali üzerinde önemli bir rolü bulunmaktadır ve bu önemini kısmen dehşeti yönetmede de görebilmekteyiz.

Yalom (2011) ölüm korkusunu insanın yaşamında merkezi bir rolünün olduğunu belirtmektedir. Vance (2014) da terapi ortamında ölümlülüğümüzün ele alınmasının terapötik bir etkisinin olabileceğinden söz etmektedir. Benlik saygısı birçok terapide önemli bir yere sahiptir ve benzer şekilde birçok kuramsal yaklaşım bir şekilde bağlanma 
sürecinin önemi üzerinde durmaktadır. Ölümlüğümüze dair farkındalığın hem benlik saygisı hem de bağlanma ile olan ilişkisi düşünüldüğünde, ölümlülüğümüzün aynı düzeyde terapi ortamında ele alınmadığı söylenebilir. Her ne kadar varoluşçu yaklaşım temelindeki terapi modellerinde ölüm temel bir konu olsa da diğer birçok terapi modelinde ihmal edildiğini görmekteyiz. Dehşet yönetimi kuramı çerçevesinde yürütülen çalışmalardan elde edilen sonuçların insan davranışlarını açıklamanın ötesinde psikoterapi gibi uygulama alanında karşılık bulması mümkün gözükmektedir.

Insanın erken dönem çocukluğundaki ebeveyniyle olan ilişkisinin diğer bir ifadeyle yaşamın başlarındaki deneyimlerinin, insanın sonu anlamına gelen ölüm algısı üzerinde belirleyici bir rolünün olabileceği ise ironik bir durumdur. Araştırmalardan elde edilen bilgilerden yola çıkılarak, ne kadar merkezi bir role sahip olduğunu söylemek mümkün görünmese de araştırmaların artmasıyla birlikte zaman içinde konunun daha da aydınlanacağ1 umut edilebilir. Buna rağmen güvenli bağlanmanın dehşeti yönetmede kolaylaştırıcı bir rolünün olduğunu söyleyebiliriz. Son olarak uzun bir süre ölüm konusundan uzak durmuş olan psikoloji biliminin (Kastenbaum, 2000) bu alanda söyleyebileceklerinin büyük önem taşıdığı da unutulmamalıdır.

\section{Kaynaklar}

Aksüt-Çiçek S (2008) Dindarlık ile saldırganlık arasındaki etkileşimin terör yönetimi kuramı çerçevesinde incelenmesi (Yüksek lisans tezi). Mersin, Mersin Üniversitesi.

Arndt J, Greenberg J, Solomon S, Pyszczynski T, Simon L (1997) Suppression, accessibility of death-related thoughts, and cultural worldview defense: exploring the psychodynamics of terror management. J Pers Soc Psychol, 73:5-18.

Arndt J, Lieberman JD, Cook A, Solomon S (2005) Terror management in the courtroom: exploring the effects of mortality salience on legal decision making. Psychol Public Policy Law, 11:407-438.

Arrowood RB, Cox CR, Ekos NV (2017) Mortality salience increases death-thought accessibility and worldview defense among high broad autism phenotype (BAP) individuals. Pers Individ Dif, 113:88-95.

Becker E (1973) The Denial of Death. New York, Free Press.

Bowlby J (1985) Attachment and Loss: Vol. 3, Loss. Great Britain, Pelican Books.

Bowlby J (1989) Attachment and Loss: Vol. 1, Attachment. Great Britain, Pelican Books.

Brassai L, Piko BF, Steger MF (2012) Existential attitudes and Eastern European adolescents' problem and health behaviors: highlighting the role of the search for meaning in life. Psychol Rec, 62:719-734.

Brown JD, Dutton KA, Cook KE (2001) From the top down: Self-esteem and self-evaluation. Cogn Emot, 15:615-631.

Chatard A, Selimbegovic L, Konan PN, Arndt J, Pyszczynski T, Lorenzi-Cioldi F, Van der Linden M (2007) Terror management in times of war: mortality salience effects on self-esteem and governmental support. J Peace Res, 48:225-234.

Chung JM, Hutteman R, van Aken MAG, Denissen JJA (2017) High, low, and in between: self-esteem development from middle childhood to young adulthood. J Res Pers, 70:122-133.

Cihan B (2013) The effects of mortality salience and body-related social norms on attitudes towards diet pills: a terror management health model perspective (Yüksek lisans tezi). Ankara, Orta Doğu Teknik Üniversitesi.

Cole DA, Maxwell ES, Martin JM, Peeke LG, Seroczynski AD, Tram JM et al. (2001) The development of multiple domains of child and adolescent self-concept: a cohort sequential longitudinal design. Child Dev, 72:1723-1746.

Cox CR, Arndt J (2012) How sweet it is to be loved by you: the role of perceived regard in the terror management of close relationships. J Pers Soc Psychol, 3:616-632.

Cox CR, Arndt J, Pyszczynski T, Greenberg J, Abdollahi A, Solomon S (2008) Terror management and adults' attachment to their parents: the safe haven remains. J Pers Soc Psychol, 94:696-717.

Dalda B (2011) The effects of relationship commitment and gender on death- anxiety among Turkish young adults: a terror management theory perspective (Yüksek lisans tezi). Ankara, Orta Doğu Teknik Üniversitesi.

Donnellan MB, Kenny DA, Trzesniewski KH, Lucas RE, Conger RD (2012) Using trait-state models to evaluate the longitudinal consistency of global self-esteem from adolescence to adulthood. J Res Pers, 46:634-645.

Du H, Jonas E, Klackl J, Agroskin D, Hui EKP, Ma L (2013) Cultural influences on terror management: independent and interdependent self-esteem as anxiety buffers. J Exp Soc Psychol, 49:1002-1011. 
Du H, Jonas E (2015) Being modest makes you feel bad: effects of the modesty norm and mortality salience on self-esteem in a collectivistic culture. Scand J Psychol, 56:86-98.

Florian V, Mikulincer M (1998) Symbolic immortality and the management of the terror of death: the moderating role of attachment style. Pers Soc Psychol, 74:725-734.

Frankl, (2015) İnsanın Anlam Arayışı (Çeviri S Budak). İstanbul, Okuyan Us.

Greenberg J, Solomon SF, Pyszczynski T (1997) Terror management theory of self-esteem and social behavior: empirical assessments and conceptual refinements. Adv Exp Soc Psychol, 29:61-139.

Greenberg J, Solomon SF, Pyszczynski T, Rosenblatt A, Burling J, Lyon D et al. (1992) Why do people need self-esteem? Converging evidence that self-esteem serves an anxiety-buffering function. J Pers Soc Psychol, 63:913-922.

Greenberg J, Pyszczynski T, Solomon S (1986) The causes and consequences of a need for self-esteem: a terror management theory. In Public Self and Private Self (Ed RF Baumeister):189-212. New York, Springer-Verlag.

Harmon-Jones E, Simon L, Pyszczynski T, Solomon S, McGregor H (1997) Terror management theory and self-esteem: Evidence that increased self-esteem reduces mortality salience effects. J Pers Soc Psychol, 72:24-36.

Harmon-Jones E, Greenberg J, Solomon S, Simon L (1996) The effects of mortality salience on intergroup bias between minimal groups. Eur J Soc Psychol, 26:677-681.

Hart J, Shaver PR, Goldenberg JL (2005) Attachment, self-esteem, worldviews, and terror management: evidence for a tripartite security system. J Pers Soc Psychol, 88:999-1013.

Hayes J, Schimel J, Arndt J, Faucher EH (2010) A theoretical and empirical review of the death-thought accessibility concept in terror management research. Psychol Bull, 136:699-739.

Hirschberger G, Florian V, Mikulincer M (2003) Strivings for romantic intimacy following partner complaint or criticism: a terror management perspective. J Soc Pers Relat, 20:675-687.

Jonas E, Fischer $P$ (2006) Terror management and religion: evidence that intrinsic religiousness mitigates worldview defense following mortality salience. J Pers Soc Psychol, 91:553-567

Josephs RA, Bosson JK, Jacobs CG (2003) Self-esteem maintenance processes: why low self-esteem may be resistant to change. Pers Soc Psychol Bull, 29:920-933.

Kastenbaum R (2000) The Psychology of Death, 3rd ed. New York, Springer Publishing.

Kuster F, Orth U, Meier LL (2013) High self-esteem prospectively predicts better work conditions and outcomes. Soc Psychol and Personal Sci, 4:668-675.

Landau M, Greenberg J (2006) Play it safe or go for the gold? A terror management perspective on self-enhancement and selfprotective motives in risky decision making. Pers Soc Psychol Bull, 32:1633-1645.

Landau M, Greenberg J, Sullivan D (2009) Managing terror when self-worth and worldview collides: Evidence that mortality salience increases reluctance to self-enhance beyond authorities. J Exp Soc Psychol, 45:68-79.

Leary MR, Tambor ES, Terdal SK, Downs DL (1995) Self-esteem as an interpersonal monitor: the sociometer hypothesis. J Pers Soc Psychol, 68:518-530.

McGregor I, Gailliot MT, Vasquez NA, Nash KA (2007) Ideological and personal zeal reactions to threat among people with high self-esteem: motivated promotion focus. Pers Soc Psychol Bull, 33:1587-1599.

Mert is (2010) Terör yönetimi kuramı ve cesaret: kavramsal bir tartışma. Güvenlik Stratejileri Dergisi, 6:57-81.

Mikulincer M, Florian V (2000) Exploring individual differences in reactions to mortality salience: does attachment style regulate terror management mechanisms? J Pers Soc Psychol, 79:260-273.

Mikulincer M, Florian V, Hirschberger G (2003) The existential function of close relationships: introducing death into the science of love. Pers Soc Psychol Rev, 7:20-40.

Mikulincer M, Florian V, Tolmacz R (1990) Attachment styles and fear of personal death: a case study of affect regulation. J Pers Soc Psychol, 58:273-280.

Mikulincer M, Florian V, Birnbaum G, Malishkevich S (2002) The death-anxiety buffering function of close relationships: exploring the effects of separation reminders on death-thought accessibility. Pers Soc Psychol Bull, 28:287-299.

Olsthoorn P (2007) Courage in the military: physical and moral. J Mil Ethics, 6:270-279.

Orth U, Robins RW (2014) The development of self-esteem. Curr Dir Psychol Sci, 23:381-387.

Orth U (2018) The family environment in early childhood has a long-term effect on self-esteem: a longitudinal study from birth to age 27 years. J Pers Soc Psychol, 114:637-655.

Orth U, Robins RW, Roberts BW (2008) Low self-esteem prospectively predicts depression in adolescence and young adulthood. J Pers Soc Psychol, 95:695-708.

Pyszczynski T (2004) What are we so afraid of? A terror management theory perspective on the politics of fear. Soc Res, 71:827848. 
Pyszczynski T, Greenberg J, Solomon S, Arndt J, Schimel J (2004) Why do people need self-esteem? A theoretical and empirical review. Psychol Bull, 130:435-468.

Routledge C, Juhl J (2010) When death thoughts lead to death fears: mortality salience increases death anxiety for individuals who lack meaning in life. Cogn Emot, 24:848-854.

Salisbury L C, Nenkov GY (2016) Solving the annuity puzzle: the role of mortality salience in retirement savings decumulation decisions. J Consum Psychol, 26:417-425.

Schimel J, Hayes J, Williams T, Jahrig J (2007) Is death really the worm at the core? Converging evidence that worldview threat increases death-thought accessibility. J Pers Soc Psychol, 92:789-803.

Schmeichel BJ, Gailliot MT, Filardo E, McGregor I, Gitter S, Baumeister RF (2009) Terror management theory and self-esteem revisited: the roles of implicit and explicit self-esteem in mortality salience effects. J Pers Soc Psychol, 96:1077-1087.

Simon L, Arndt J, Greenberg J, Pyszczynski T, Solomon S (1998) Terror management and meaning: evidence that the opportunity to defend the worldview in response to mortality salience increases the meaningfulness of life in the mildly depressed. J Pers, 66:359-382.

Steger MF, Fitch-Martin AR, Donnelly J, Rickard KM (2015) Meaning in life and health: proactive health orientation links meaning in life to health variables among American undergraduates. J Happiness Stud, 16:583-397.

Steger MF, Kashdan TB, Sullivan BA, Lorentz D (2008) Understanding the search for meaning in life: personality, cognitive style, and the dynamic between seeking and experiencing meaning. J Pers, 76:199-228.

Strachman A, Schimel J (2006) Terror management and close relationships: evidence that mortality salience reduces commitment among partners with different worldviews. J Soc Pers Relat, 23:965-978.

Taubman Ben-Ari 0 (2011) Is the meaning of life also the meaning of death? A terror management perspective reply. J Happiness Stud, 12:385-399.

Taubman Ben-Ari 0, Findler L, Mikulincer M (2002) The effects of mortality salience on relationship strivings and beliefs: The moderating role of attachment style. Br J Soc Psychol, 41:419-441.

Van Tongeren DR, Green JD, Davis DE, Worthington EL, Reid CA (2013) Till death do us part: terror management and forgiveness in close relationships. Pers Relat, 20:755-768.

Vance LM (2014) Death anxiety and the relational. J Humanist Psychol, 54:414-433.

Verschueren K, Marcoen A (1999) Representation of self and socioemotional competence in kindergartners: differential and combined effects of attachment to mother and to father. Child Dev, 70:183-201.

Wojtkowiak J, Rutjens BT (2011) The postself and terror management theory: reflecting on after death identity buffers existential threat. Int J Psychol Relig, 21:137-144.

Yaakobi E, Mikulincer M, Shaver PR (2014) Parenthood as a terror management mechanism: the moderating role of attachment orientations. Pers Soc Psychol Bull, 40: 762-774.

Yalom ID (2001) Varoluş̧̧u Psikoterapi (Çeviri Zi Babayiğit). İstanbul, Kabalıı Yayınevi.

Yavuz $\mathrm{H}$, Van den Bos K (2009) Effects of uncertainty and mortality salience on worldview defense reactions in Turkey. Soc Justice Res, 22:384-398.

Yek MH, Olendzki N, Kekecs Z, Patterson V, Elkins G (2017) Presence of meaning in life and search for meaning in life and relationship to heath anxiety. Psychol Rep, 120:383-390.

Yazarların Katkıları: Her yazarın araştırmaya önemli bir bilimsel katkı yaptığını ve yazının taslağının hazıılanması veya gözden geçirilmesine yardımcı olduğu tüm yazarlar tarafından onaylanmıştır..

Danışman Değerlendirmesi: Dış bağımsız

Çıkar Çatışması: Yazarlar çıkar çatışması bildirmemiştir.

Finansal Destek: Yazarlar bu çalışma için finansal destek almaklarını beyan etmişlerdir.

Authors Contributions: All authors attest that each author has made an important scientific contribution to the study and has assisted with the drafting or revising of the manuscript.

Peer-review: Externally peer-reviewed.

Conflict of Interest: No conflict of interest was declared by the authors.

Financial Disclosure: The authors declared that this study has received no financial support. 